\title{
Discovering the thermophiles microbial diversity of Malaysian hot spring in Ulu Slim, Perak
}

\author{
Mardani Abdul Halim ${ }^{1,2}$, Nurlina Rosli' ${ }^{1}$, Farisya Izzyani Dzulkifli' ${ }^{\text {, Nazalan Najimudin }}{ }^{1,2}$ and \\ Kamarul Zaman Zarkasi ${ }^{1 *}$
}

\author{
${ }^{1}$ School of Biological Sciences, Universiti Sains Malaysia, 11800 Penang, Malaysia. \\ ${ }^{2}$ USM-RIKEN International Centre for Ageing Science (URICAS), Universiti Sains Malaysia, 11800 Penang, Malaysia. \\ Email: kamarul.zarkasi@gmail.com
}

Received 24 August 2019; Received in revised form 3 December 2019; Accepted 20 December 2019

\begin{abstract}
Aims: Hot springs are major sources of useful thermophilic microbes. Our study therefore aimed at documenting and analysing the microbial communities at Ulu Slim hot spring in Perak, Malaysia, for bacteria with beneficial enzymes for industrial applications.

Methodology and results: The study sampled water and sediment materials from the Ulu Slim hot spring at two sublocations of different temperatures, $45^{\circ} \mathrm{C}$ and $72^{\circ} \mathrm{C}$. The samples were then extracted for genomic DNA, followed by paired-end metagenome sequencing using prokaryotic-conserved, locus specific primers for 16S rRNA V3 and V4 domains, and Illumina MiSeq $(2 \times 300)$ sequencing platform. Raw data were optimized using Trimmomatic and FLASH, followed by operational taxonomy units (OUT) determination and clustering. 16S rRNA gene sequences were then analysed against Silva (SSU123) 16S rRNA gene databases for phylum and genus classifications. Data analysis showed relevant alignment of present bacteria phyla against data from a previous study on Ulu Slim hot springhead, though the different sample temperatures significantly affected phylum and genus composition. Our study also confirmed the presence of a site-specific genus, Fervidobacteria, which are anaerobic bacteria with a unique ability in degrading keratin.

Conclusion, significance and impact of study: The study further completes and complement the findings on microbial communities at the Ulu Slim hot spring. The findings help to reveal the associations between microbes and environmental factors at thermophilic locations, as well as potential thermostable enzymes like lipase and amylase that can be isolated from thermophilic sample as they are indispensable for industry.
\end{abstract}

Keywords: Thermophiles, hot spring, metagenome, 16S rRNA, diversity

\section{INTRODUCTION}

Extremophiles are organisms that can survive in extreme conditions, which include thermophiles, psychrophiles, barophiles, halophiles and many more. Thermophiles, in particular, are organisms that thrive at relatively high temperatures, i.e. between $41^{\circ} \mathrm{C}$ and $122{ }^{\circ} \mathrm{C}$ (Takai et al., 2008). The term "thermophile" is derived from Greek words "thermotita", meaning heat, and "philia", meaning love. Thermophilic organisms are widely distributed across the Archaea and Bacteria domains, though there are also "thermophilic eukaryotes" that can survive in temperatures of up to $50{ }^{\circ} \mathrm{C}$ to $60{ }^{\circ} \mathrm{C}$ (Brock, 1986; Elazzazy et al., 2015; Kastritis et al., 2017; Mohammad et al., 2017). In addition, some thermophiles can also live under additional harsh conditions such as high salt concentrations and extreme pH (Fütterer et al., 2004; Giaveno et al., 2013; Urbieta et al., 2014). The thermophilic microbiology field was started in the late 1970s where the pioneering work was done by Thomas Brock (Brock, 2001). The work was further expanded in the 1980s when Karl Stetter and his team extensively isolated hyperthermophiles (Stetter, 1996). Table 1 summaries previously reported thermophiles.

Hot springs are one of the many sources where thermophiles can be isolated from. A hot spring is created as a result of geothermally heated groundwater from the Earth's crust. Hot spring water usually contains high concentrations of minerals, because when the heated groundwater passes through the Earth's surface, it dissolves the minerals along the way and thus form highly mineralized water. The elements and minerals found in hot-spring water include carbon dioxide $\left(\mathrm{CO}_{2}\right)$, hydrogen sulfide $\left(\mathrm{H}_{2} \mathrm{~S}\right)$, methane $\left(\mathrm{CH}_{4}\right)$, hydrogen $\left(\mathrm{H}_{2}\right)$ as well as ammonia $\left(\mathrm{NH}_{3}\right)$ (Brock, 1985). In addition, hot-spring water may be acidic or alkaline, owing to the interaction 
Table 1: Example of previous reported thermophilic metagenome studies.

\begin{tabular}{|c|c|c|}
\hline Hot spring name & $\begin{array}{c}\text { Temperature } \\
\left({ }^{\circ} \mathrm{C}\right)\end{array}$ & References \\
\hline Jim's Black Pool (USA) & 74 & $\begin{array}{l}\text { Barns et al., } \\
1994\end{array}$ \\
\hline $\begin{array}{l}\text { Domas and Cibumi } \\
\text { (Indonesia) }\end{array}$ & $82-90$ & $\begin{array}{l}\text { Baker et al., } \\
2001\end{array}$ \\
\hline $\begin{array}{l}\text { Boiling Spring Lake } \\
\text { (USA) }\end{array}$ & 55 & $\begin{array}{l}\text { Wilson et al., } \\
2008\end{array}$ \\
\hline Bison Pool (USA) & 40 & $\begin{array}{l}\text { Swingley et } \\
\text { al., } 2012\end{array}$ \\
\hline $\begin{array}{l}\text { Hot spring Mutnovsky } \\
\text { Volcano (Russia) }\end{array}$ & 70 & $\begin{array}{l}\text { Wemheuer et } \\
\text { al., } 2013\end{array}$ \\
\hline $\begin{array}{l}\text { Kirishima Natural Park } \\
\text { (Japan) }\end{array}$ & $66-93$ & $\begin{array}{l}\text { Satoh et al., } \\
2013\end{array}$ \\
\hline $\begin{array}{l}\text { Three heart lake Geyser } \\
\text { Basin (USA) }\end{array}$ & $44-75$ & $\begin{array}{l}\text { De León et } \\
\text { al., } 2013\end{array}$ \\
\hline $\begin{array}{l}\text { Hydrothermal ponds in } \\
\text { Copahue (Argentina) }\end{array}$ & 87 & $\begin{array}{l}\text { Urbieta et al., } \\
2014\end{array}$ \\
\hline $\begin{array}{l}\text { Kapkai and Waramung } \\
\text { spring (Papua New } \\
\text { Guinea) }\end{array}$ & $>90$ & $\begin{array}{l}\text { Millard et al., } \\
2014\end{array}$ \\
\hline
\end{tabular}

between the dissolvent in the water and the rock forming minerals. Hot springs occur in many countries around the world including Iceland, New Zealand, Japan and most notably the Yellowstone National Park in Wyoming, USA (Mehta and Satyanarayana, 2013). Various thermophiles have been isolated from terrestrial hot springs and their diversity were identified via rRNA genes sequencing (Barns et al., 1996; Burton and Norris, 2000; Murakami et al., 2011; Goh et al., 2011). Examples include the thermophilic ammonia-oxidizing bacteria isolated from a geothermal spring in Kamchatka (Golovacheva, 1976) and nitrate-reducing bacteria Geobacillus gargensis sp. nov. isolated in Garga spring (Nazina et al., 2004). The 16S rRNA culture independent technique also revealed the existence of Nitrospira at a subterranean hot spring in Iceland (Marteinsson et al., 2001), as well as novel, moderately thermophilic thiosulfate-oxidizing bacterium, Thiomonas bhubaneswarensis sp. nov. isolated from a hot spring sediment in Bhubaneswar, India (Panda et al., 2009). This culture independent technique is not only utilized to study microbial residents in hot springs (Inskeep et al., 2013), but have also been used to study coastal water microbes (Somboonna et al., 2012; Zarkasi and Nazari, 2018; Suhaimi et al., 2019; Zarkasi et al., 2019), microbes that colonize human tongues (Jiang et al., 2012) and many more.

The culture-independent technique, or commonly known as metagenomic sequencing, is a powerful tool that can deliver key insights on the structure and metabolic capacity of a whole community of microorganisms being studied. For example, genes involved in $\mathrm{H}_{2}$ oxidation appear dominant in $\mathrm{H}_{2}$-rich hydrothermal vent community (Brazelton et al., 2012), while the sulphur-cycling genes were found to be present in most genera living in deep sea hydrothermal vents (Cao et al., 2014). Besides, metagenomic data can also be exploited to validate metabolic functionalities that are predicted from physiochemical analyses (He et al., 2013). In the genomic era, the contribution of metagenomic techniques in microbial community studies proved to be indispensable. Metagenomic data can deliver unpredicted insights into the structure of community as well as their functions associated with the environments (Zarkasi et al., 2017; Hussin et al., 2018; Lau et al., 2019). In this study, we take advantage of the powerful metagenomic sequencing technique to explore the diversity of microbial community at one of Malaysia's hot springs in Ulu Slim, Perak, providing significant addition to the database of microbial diversity of hot springs.

The Ulu Slim hot spring is located on the western side of Malaysia's Banjaran Titiwangsa, the biggest mountain range in Peninsular Malaysia that is non-volcanic with a tropical climate (Chow et al., 2010). Hot springs along this mountain range are heated geothermally, as opposed to hot springs in tectonically active zones such as the Yellowstone National Park hot springs in the Unites States. At the latter, subsurface magma heats up rain or melted snow to form superheated water bodies which are usually acidic in nature. On the other hand, non-volcanic hot springs such as Ulu Slim are circumneutral or slightly alkaline. Several phyla have so far been found and documented from the Ulu Slim hot springs, such as Aquificae, Chlorobi, Thermotogae, Proteobacteria and Firmicutes (Chan et al., 2017). However, we believe that there are still more prokaryotes to be explored at Ulu Slim, seeing as existing studies did not include samples with a wide range of temperature. Therefore, our study aimed to further explore the microbial diversity of Ulu Slim hot springs by sampling at two sublocations with two different temperatures, which are $45^{\circ} \mathrm{C}$ and $72{ }^{\circ} \mathrm{C}$.

\section{MATERIALS AND METHODS}

\section{Sample collection and analysis}

The Ulu Slim hot spring was located in the Perak state $\left(3^{\circ} 89^{\prime} 88.22^{\prime \prime} \mathrm{N}, 101^{\circ} 49^{\prime} 79^{\prime \prime} \mathrm{E}\right)$ of Malaysia. Water and sediment samples were collected from two locations (72 ${ }^{\circ} \mathrm{C}$ and $45^{\circ} \mathrm{C}$ ), both away from the main flowing spring. The collected samples were stored at $4{ }^{\circ} \mathrm{C}$ prior to genomic DNA extraction.

\section{Genomic DNA extraction}

The mixture of water and sediments were shaken vigorously prior to the extraction. The mixture was then briefly centrifuged to just precipitate coarse particles. Genomic DNA was then extracted using NucleoSpin ${ }^{\circledR}$ Soil (Macherey-Nagel, Germany) according to manufacturer's suggested protocol. The extracted genomic DNA was evaluated by $1 \%$ agarose gel 
Malays. J. Microbiol. Vol 16(3) 2020, pp. 184-192

DOI: http://dx.doi.org/10.21161/mjm. 190564

electrophoresis and quantified using QuantiFluorTM-ST (Promega, USA).

\section{Library preparation and sequencing}

The purified genomic DNA was used to generate 16S rRNA library. The primers used for this study were 5'TCGTCGGCAGCGTCAGATGTGTATAAGAGACAGCCT ACGGGNGGCWGCAG-3' and GTCTCGTGGGCTCGGAGATGTGTATAAGAGACAGGA CTACHVGGGTATCTAATCC-3' in which the underlined nucleotides are locus specific of prokaryotic conserved 16S rRNA V3 and V4 domains while the non-underlined nucleotides are the Illumina overhang adapter sequences (Klindworth et al., 2013; Zarkasi et al., 2018). Paired-end sequencing was performed using Illumina MiSeq $(2 \times$ 300) sequencing platform.

\section{Downstream bioinformatics analysis}

Raw data generated from the Illumina MiSeq sequencing platform were quality controlled using Trimmomatic (Bolger et al., 2014), where any truncated reads that were shorter than $50 \mathrm{bp}$ were discarded. The paired-end reads that passed the quality check with sequences that overlapped longer than 10 bp were merged using FLASH (Magoč and Salzberg, 2011). 'Qualitative Insights Into Microbial Ecology' (QIIME) (Caporaso et al., 2010) was used to determine the operational taxonomy units (OTU) that corresponded to the 16S rRNA sequences in each sample. The OTUs were clustered with default $97 \%$ similarity cutoff using UPARSE (Edgar, 2013) (version 7.1) and chimeric sequences were identified using UCHIME (Edgar et al., 2011). The taxonomy of each 16S rRNA gene was analyzed using RDP Classifier (Wang et al., 2007) against Silva (SSU123) 16S rRNA gene databases (Quast et al., 2012) using confidence threshold of 0.7 .

\section{RESULTS}

\section{Raw data statistics}

A total of $97,663,664$ raw bases were generated for both samples $45^{\circ} \mathrm{C}$ (sample 45) and $72{ }^{\circ} \mathrm{C}$ (sample 72). Quality-filtered raw reads produced a total of $70,885,407$ clean bases in which $37,626,577$ bases belong to sample 45 while $33,258,830$ bases belong to sample 72 with average length of 437.25 and 436.58 bases respectively. The length distribution for the cleaned reads is further illustrated in Table 2. Raw data was deposited to NCBI under BioProject ID: PRJNA561450.

\section{OTU clustering and taxonomic classification}

A total of 194 OTUs in sample 45 and 171 OTUs in sample 72 were identified, and all the OTUs were classified as belonging to the Bacteria domain. Following phylum classification in sample 45 , a total of 16 phyla and one unclassified phylum were identified. Firmicutes
Table 2: The total distribution of clean reads generated from Illumina sequencing. Majority of the sequences had an average length of $421 \mathrm{bp}$ to $460 \mathrm{bp}$.

\begin{tabular}{ccc}
\hline Length (bp) & Number of sequences & Percent (\%) \\
\hline $361-380$ & 9 & 0.01 \\
$381-400$ & 13 & 0.01 \\
$401-420$ & 169 & 0.10 \\
$421-440$ & 87565 & 53.98 \\
$441-460$ & 74408 & 45.87 \\
$461-480$ & 39 & 0.02 \\
$481-500$ & 16 & 0.01 \\
\hline
\end{tabular}

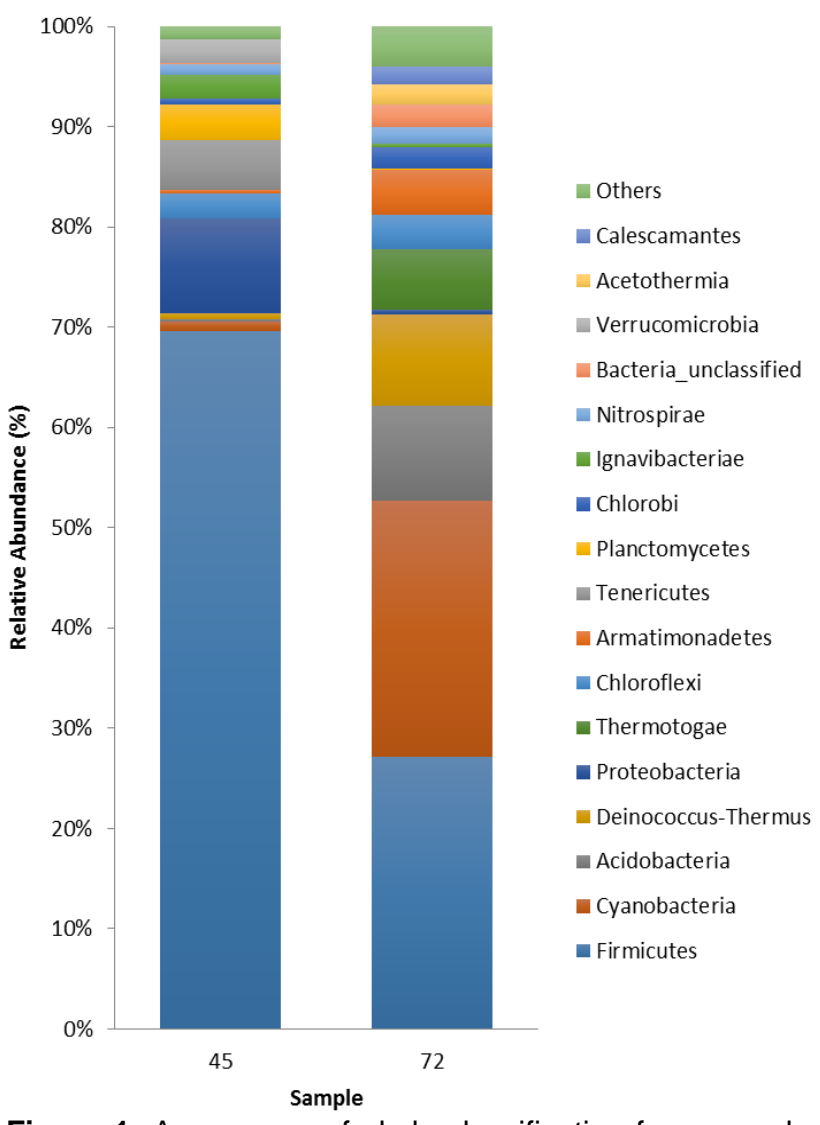

Figure 1: A summary of phyla classification from sample 45 and 72 . The most abundance phyla identified in both samples 45 and 72 was Firmicutes with $69.59 \%$ and $27.12 \%$ of abundance respectively.

dominate more than half of the total identified phyla, with $69.59 \%$ in abundance, followed by Proteobacteria at $9.37 \%$ and Tenericutes at $4.95 \%$. For sample 72 , a total of 16 phyla and one unclassified phylum were identified. Similarly, Firmicutes was among the most dominant phylum with $27.12 \%$ abundance, followed by Cyanobacteria at $25.52 \%$ abundance and Acidobacteria at $9.45 \%$ abundance. The most significant difference between sample 45 and 72 was the presence of the phylum Tenericutes only in the former. On the other hand, 


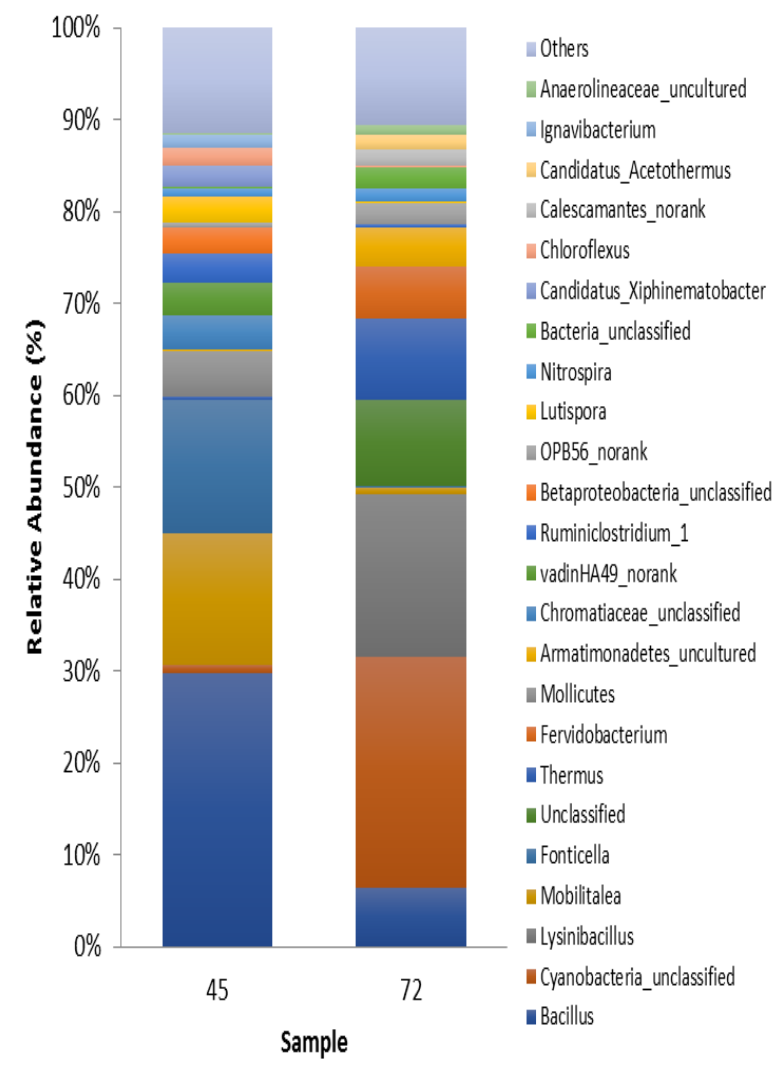

Figure 2: The summary of genus distribution for sample 45 and 72 . In sample 45, the genus Bacillus was the most abundance compared to other genus with relative abundance of $29.81 \%$. On the other hand, unclassified cyanobacteria dominating the genus distribution in sample 72 with $25.06 \%$ abundance.

phylum Calescamantes was exclusively present in sample 72. A summary of total phylum distribution in sample 45 and 72 was shown in Figure 1. Under genus classification, Bacillus was the most abundant genus with $29.81 \%$ presence in sample 45 while unclassified Cyanobacteria was the most abundant genus in sample 72 at $25.06 \%$. Overall summary of genus identification in sample 45 and 72 was shown in Figure 2. Both samples have attained richness saturation as shown in the rarefaction curve (Figure 3).

\section{DISCUSSION}

The emergence of high-throughput sequencing technologies gave birth to the culture-independent method of studies to determine microbial communities in certain niches, bypassing several limitations of culturebased methods (Sharon and Banfield, 2013). In this study, we take advantage of the culture-independent metagenomic sequencing method to explore the microbial diversity at the Ulu Slim hot spring in Perak, with particular interest in thermophilic microorganisms due to

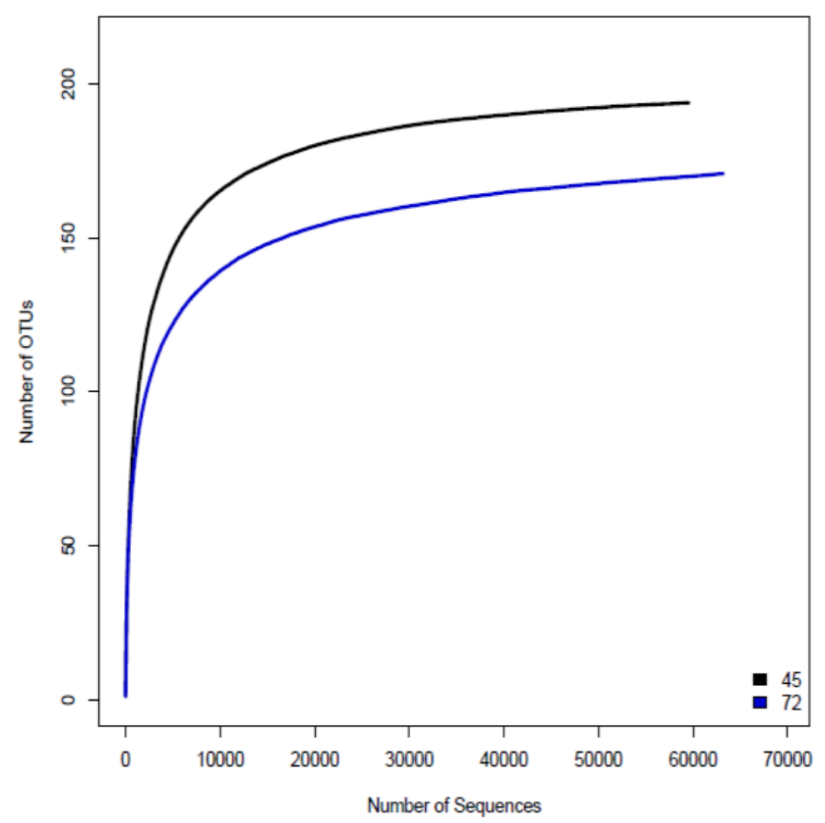

Figure 3: Rarefaction curve for sample 45 and 72 . The curve is generated based on statistical method Chao1 to estimate microbial richness in the samples. Both samples reached a horizontal asymptote and thus can be concluded that sufficient observation have been made to get a reasonable estimate of a quantity that has been measured by sampling.

their potentials in biotechnological applications such as production of thermostable enzymes (Bergquist et al., 2014).

We characterized the microbial communities of the Ulu Slim hot spring based on samples collected at two sub-locations away from the springhead, which differ by temperature, $45^{\circ} \mathrm{C}$ (sample 45 ) and $72{ }^{\circ} \mathrm{C}$ (sample 72). Based on phylum classification, both samples appeared to be mostly dominated by the phylum Firmicutes (Figure 1). However, in sample 72, Firmicutes and Cyanobacteria were dominating at almost similar levels $(27.12 \%$ and $25.52 \%$ respectively), whereas in sample 45 , Cyanobacteria was present at only $0.01 \%$ abundance. The outcome in sample 72 is similar to a previous study on microbial mats at Tibetan hot springs, which recorded 24-31\% Cyanobacteria population (Lau et al., 2009). But sample 45 was expected to have a higher abundance of Cyanobacteria, seeing as sample 72 had a temperature that is close to the maximum limit for photosynthesis by Cyanobacteria, which is $75^{\circ} \mathrm{C}$ (Ferris and Ward, 1997). Other locations with hot spring temperatures between 55$65^{\circ} \mathrm{C}$ also showed abundance of Cyanobacteria (Kubo et al., 2011; Nishiyama et al., 2013; Badhai et al., 2015). In our study, the lack of Cyanobacteria in sample 45 as opposed to sample 72 could be due to several reasons. It could be that the Cyanobacteria population in sample 45 were not in biofilm/microbial mats form, but only freeswimming Cyanobacteria, hence reflecting the low population number. Lack of biofilm formation may be due 
to several factors, for example, there could be lack of suitable surfaces where sample 45 was taken for the Cyanobacteria to start attachments and form films, such as rocks and tree roots (Watnick and Kolter, 2000). Another possible reason is the lack of nutrients available to support a biofilm community at the hot spring area. Bacteria have been known to detach from large biofilms when nutrients are scarce to ensure its survival (Allison et al., 1998).

This 'blue-green algae' prokaryote obtain their energy through photosynthesis and produces oxygen. They commonly grow in freshwater, marine, cold or hot springs, and terrestrial habitats, where symbiotic relationships with plants, fungi and algae may form in some of these habitats (Dvořák et al., 2017). Delving deeper into the diversity of cyanobacteria in hot spring areas are important to further uncover beneficial secondary metabolites produced by this group of bacteria, as past studies have shown their high value and demand in several industries (Kultschar and Llewellyn, 2018).

Overall, however, the diversity profiles of sample 45 and 72 were similar to several profiles of other hot spring locations, such as in Eritrea (Ghilamicael et al., 2017), Sungai Klah (Malaysia) (Chan et al., 2015), and central India (Saxena et al., 2017), where Firmicutes and Proteobacteria are typically most dominant. However, when compared to a previous study conducted at Ulu Slim hot spring, where the sample was obtained at the springhead at a temperature of $80-110{ }^{\circ} \mathrm{C}$, the metagenome profile was markedly different to our findings. The dominating phyla in their study sample were Aquificae and Thermotogae, both known for hyperthermophilia, and Firmicutes was among the least abundant phylum at only $11.1 \%$ (Chan et al., 2017). It is thus noted that temperature differences at sampling locations, even though at the same hot spring area, significantly affect microbial diversity. It was also noted that no Cyanobacteria was detected in the springhead sample study, as the springhead temperature was higher than the maximum limit of temperature for photosynthesis to occur (Ferris and Ward, 1997; Chan et al., 2017). It was thus obvious that changes in temperature within the same hot spring area causes significant differences in microbial diversity and functions. As such, our study adds diversity and complements current findings on microbial diversity profile of Ulu Slim hot spring area, since our study sampled the Ulu Slim hot spring sublocations at different temperatures.

Despite that, it must be noted that the phylum Firmicutes were consistently present in both the previous and current study on Ulu Slim hot spring. Not only that, Firmicutes are also commonly featured in four other hot springs sampled around Malaysia (Chan et al., 2017). In the previous study by Chan et al. (2017), the $80-110{ }^{\circ} \mathrm{C}$ hot spring samples at Ulu Slim showed that the Firmicutes phylum present were dominated by the class Clostridia $(89.6 \%)$ of the order Clostridiales, which are obligate anaerobes and endospore forming bacteria (Chan et al., 2017). In our study, phylum Firmicutes in sample 45 was almost equally dominated by the class
Clostridia (34.8\%) and Bacilli $(30 \%)$, whereas in sample 72 , Clostridia comprise of only $0.01 \%$ of the phylum and Bacilli at $24.1 \%$. They include genera such as Bacillus (Bacilli), Lysinibacillus (Bacilli), Mobilitalea (Clostridia), Fonticella (Clostridia), Ruminiclostridium (Clostridia), and Lutispora (Clostridia). Firmicutes are typically made up of Gram-positive microorganisms with rigid or semi-rigid cell walls (Gibbons and Murray, 1978), with some producing endospores as a survival strategy against environmental stresses such as heat (Jumas-Bilak et al., 2009). The marked reduction in population of the class Clostridia in sample 72 was quite significant, which is suspected to be due to differences at the two sample sites in terms of oxygen presence. Despite both being spore-forming microorganisms, Clostridia are strictly anaerobes while Bacilli are aerobes. It is thus suspected that the microenvironment where sample 72 was taken was highly exposed to oxygen, which could be a result of turbulent or fast water current flowing from the hot spring.

Another noteworthy finding from our study is the presence of a site-specific genus that was also previously found by Chan et al. (2017) at Ulu Slim, called Fervidobacteria (Chan et al., 2017). It is considered as site-specific because it was not found in five other hot springs in Malaysia, despite all the hot springs having similar dominant phyla, only of different compositions. Fervidobacterium is a bacterial genus belong to the phylum Thermotogae, featuring anaerobic, Gramnegative rod-shaped bacteria that are motile and nonsporulating. Several species of this genus come with a few unique characteristics. One of them is having a twolayered cell wall, where the outer layer often forms spheroids, which are terminal swellings of the cells (Patel et al., 1985).

Another more important characteristic of Fervidobacterium is the ability of some species to produce a thermostable keratinase, allowing them to degrade keratin (i.e. bird feathers) into peptides and amino acids (Friedrich and Antranikian, 1996; Kim et al., 2004; Lee et al., 2015). The responsible serine protease enzyme by the Fervidobacterium pennivorans is deemed valuable for potential application in the poultry industry, where bird feathers are discarded in bulk and need to be managed effectively, or in the effort of converting biomass to biofuels at high temperature.

The keratin in feathers are made up of $\alpha$-helices ( $\alpha$ keratin) or pleated $\beta$-sheets ( $\beta$-keratins) held together by hydrogen $(H)$ bonds and disulfide crosslinks. The pleated $\beta$-sheets, in particular, make keratin very rigid, and hence cannot be simply broken down via proteolysis (Suzuki et al., 2006; Strasser et al., 2015). Interest in microbe's ability to degrade keratin have been building up recently. In 2018, a study successfully utilized Fervidobacterium islandicum AW-1 to anaerobically digest native chicken feathers as part of a process to produce low molecular weight keratins for potential use in cosmetic products (Yeo et al., 2018). This effort is also being optimized at an industrial scale by Jin et al. (2019), aiming to produce keratin in a more environmentally sustainable manner using discarded feathers. Utilizing extremophiles such as 
hot spring bacteria for this process may have an added advantage when keratin needs to be processed at high temperatures (Nam et al., 2002).

Even though our study was not distinguishing the species of Fervidobacteria that was isolated at the Ulu Slim hot spring, it seems feasible as a future step to properly isolate and culture the bacteria for its potential industrial value. Moreover, the only other places where thermophilic Fervidobacteria have been found and documented so far are outside of Malaysia, namely India (Saxena et al., 2017), Thailand (Kanoksilapatham et al., 2016) and China (Cai et al., 2007) between the time period of 1985 and 2007.

\section{CONCLUSION}

This metagenomic study effectively provides a more extensive microbial diversity profile of the Ulu Slim hot spring, as well as reinforcing the discovery of site-specific taxa at the location (i.e. Fervidobacteria). The study also showed that microbial profiles can dramatically change with slight changes in temperature, what more external factors such as climate change and abiotic factors that may accumulate over time. This was apparent from the different phyla compositions when compared to a previous study. It is thus crucial that further exploration of specific genus at this location becomes the next step, such as the high-potential Fervidobacteria.

\section{ACKNOWLEDGEMENTS}

We thank all our colleagues and collaborators for providing critical reviews for this project. This work is funded by ScienceVision Sdn Bhd and USM RUI research grant (1001/PBIOLOGI/8011007). Mardani Abdul Halim is supported by USM research university top-down grant (URICAS) (1001/PBIOLOGI/870040).

\section{REFERENCES}

Allison, D. G., Ruiz, B., SanJose, C., Jaspe, A. and Gilbert, P. (1998). Extracellular products as mediators of the formation and detachment of Pseudomonas fluorescens biofilms. FEMS Microbiology Letters 167(2), 179-184.

Badhai, J., Ghosh, T. S. and Das, S. K. (2015). Taxonomic and functional characteristics of microbial communities and their correlation with physicochemical properties of four geothermal springs in Odisha, India. Frontiers in Microbiology 6, 1166.

Baker, G. C., Gaffar, S., Cowan, D. A. and Suharto, A. R. (2001). Bacterial community analysis of Indonesian hot springs. FEMS Microbiology Letters 200(1), 103109.

Barns, S. M., Delwiche, C. F., Palmer, J. D. and Pace, N. R. (1996). Perspectives on archaeal diversity, thermophily and monophyly from environmental rRNA sequences. Proceedings of the National Academy of Sciences 93(17), 9188-9193.
Barns, M., Fundyga, R. E., Jeffries, M. W. and Pace, N. R. (1994). Remarkable archaeal diversity detected in a Yellowstone National Park hot spring environment. Proceedings of the National Academy of Sciences 91(5), 1609-1613.

Bergquist, P. L., Morgan, H. W. and Saul, D. (2014). Selected enzymes from extreme thermophiles with applications in biotechnology. Current Biotechnology 3(1), 45-59.

Bolger, A. M., Lohse, M. and Usadel, B. (2014). Trimmomatic: A flexible trimmer for Illumina sequence data. Bioinformatics 30(15), 2114-2120.

Brazelton, W. J., Nelson, B. and Schrenk, M. O. (2012). Metagenomic evidence for $\mathrm{H}_{2}$ oxidation and $\mathrm{H}_{2}$ production by serpentinite-hosted subsurface microbial communities. Frontiers in Microbiology 2, 268.

Brock, T. D. (1985). Life at high temperatures. Science 185, 1012-1019.

Brock, T. D. (1986). Thermophiles: General, Molecular, and Applied Microbiology. John Wiley \& Sons, Michigan. pp. 1-316.

Brock, T. D. (2001). The origins of research on thermophiles. In: Thermophiles Biodiversity, Ecology, and Evolution. Reysenbach, A. L., Voytek, M. and Mancinelli R. (eds.). Springer, Boston, Massacchusetts. pp. 1-9.

Burton, N. P. and Norris, P. R. (2000). Microbiology of acidic, geothermal springs of Montserrat: Environmental rDNA analysis. Extremophiles 4(5), 315-320.

Cai, J., Wang, Y., Liu, D., Zeng, Y., Xue, Y., Ma, Y. and Feng, Y. (2007). Fervidobacterium changbaicum sp. nov., a novel thermophilic anaerobic bacterium isolated from a hot spring of the Changbai Mountains, China. International Journal of Systematic and Evolutionary Microbiology 57(Pt 10), 2333-2336.

Cao, H., Wang, Y., Lee, O. O., Zeng, X., Shao, Z. and Qian, P.-Y. (2014). Microbial sulfur cycle in two hydrothermal chimneys on the Southwest Indian Ridge. mBio 5(1), e00980-13.

Caporaso, J. G., Kuczynski, J., Stombaugh, J., Bittinger, K., Bushman, F. D., Costello, E. K. et al. (2010). QIIME allows analysis of high-throughput community sequencing data. Nature Methods 7(5), 335-336.

Chan, C. S., Chan, K.-G., Ee, R., Hong, K.-W., Urbieta, M. S., Donati, E. R., Shamsir, M. S. and Goh, K. M. (2017). Effects of physiochemical factors on prokaryotic biodiversity in Malaysian circumneutral hot springs. Frontiers in Microbiology 8, 1252.

Chan, C. S., Chan, K.-G., Tay, Y.-L., Chua, Y.-H. and Goh, K. M. (2015). Diversity of thermophiles in a Malaysian hot spring determined using 16S rRNA and shotgun metagenome sequencing. Frontiers in Microbiology 6, 177.

Chow, W. S., Irawan, S. and Fathaddin, M. T. (2010). Hot springs in the Malay Peninsula. Proceedings World Geothermal Congress 2010, 1-5. 
De León, K. B., Gerlach, R., Peyton, B. M. and Fields, M. W. (2013). Archaeal and bacterial communities in three alkaline hot springs in Heart Lake Geyser Basin, Yellowstone National Park. Frontiers in Microbiology 4, 330.

Dvořák, P., Casamatta, D. A., Hašler, P., Jahodářová, E., Norwich, A. R. and Poulíčková, A. (2017). Diversity of the cyanobacteria. In: Modern Topics in the Phototrophic Prokaryotes. Hallenbeck, P. (ed.). Springer, Cham. pp. 3-46.

Edgar, R. C. (2013). UPARSE: Highly accurate OTU sequences from microbial amplicon reads. Nature Methods 10(10), 996-998.

Edgar, R. C., Haas, B. J., Clemente, J. C., Quince, C. and Knight, R. (2011). UCHIME improves sensitivity and speed of chimera detection. Bioinformatics 27(16), 2194-2200.

Elazzazy, A. M., Abdelmoneim, T. S. and Almaghrabi, O. A. (2015). Isolation and characterization of biosurfactant production under extreme environmental conditions by alkali-halo-thermophilic bacteria from Saudi Arabia. Saudi Journal of Biological Sciences 22(4), 466-475.

Ferris, M. J. and Ward, D. M. (1997). Seasonal distributions of dominant 16S rRNA-defined populations in a hot spring microbial mat examined by denaturing gradient gel electrophoresis. Applied and Environmental Microbiology 63(4), 1375-1381.

Friedrich, A. B. and Antranikian, G. (1996). Keratin degradation by Fervidobacterium pennavorans, a novel thermophilic anaerobic species of the order Thermotogales. Applied and Environmental Microbiology 62(8), 2875-2882.

Fütterer, O., Angelov, A., Liesegang, H., Gottschalk, G., Schleper, C., Schepers, B., Dock, C., Antranikian, G. and Liebl, W. (2004). Genome sequence of Picrophilus torridus and its implications for life around $\mathrm{pH}$ 0. Proceedings of the National Academy of Sciences 101(24), 9091-9096.

Ghilamicael, A. M., Budambula, N. L. M., Anami, S. E., Mehari, T. and Boga, H. I. (2017). Evaluation of prokaryotic diversity of five hot springs in Eritrea. BMC Microbiology 17(1), 203.

Giaveno, M. A., Urbieta, M. S., Ulloa, J. R., Toril, E. G. and Donati, E. R. (2013). Physiologic versatility and growth flexibility as the main characteristics of a novel thermoacidophilic Acidianus strain isolated from Copahue geothermal area in Argentina. Microbial Ecology 65(2), 336-346.

Gibbons, N. E. and Murray, R. G. E. (1978). Proposals concerning the higher taxa of bacteria. International Journal of Systematic Bacteriology 28(1), 1-6.

Goh, K. M., Chua, Y. S., Rahman, R. N. Z. R. A., Chan, R. and Illias, R. M. (2011). A comparison of conventional and miniprimer PCR to elucidate bacteria diversity in Malaysia Ulu Slim hot spring using 16S rDNA clone library. Romanian Biotechnological Letters 16(3), 6247-6255.
Golovacheva, R. S. (1976). Thermophilic nitrifying bacteria from hot springs. Mikrobiologiia 45(2), 298301.

He, Y., Xiao, X. and Wang, F. (2013). Metagenome reveals potential microbial degradation of hydrocarbon coupled with sulfate reduction in an oil-immersed chimney from Guaymas Basin. Frontiers in Microbiology 4, 148.

Hussin, N. A., Zarkasi, K. Z. and Ab Majid, A. H. (2018). Characterization of gut bacterial community associated with worker and soldier castes of Globitermes sulphureus Haviland (Blattodea: Termitidae) using 16S rRNA metagenomic. Journal of Asia-Pacific Entomology 21, 1268-1274.

Inskeep, W. P., Jay, Z. J., Tringe, S. G., Herrgard, M. and Rusch, D. B. (2013). The YNP metagenome project: Environmental parameters responsible for microbial distribution in the Yellowstone geothermal ecosystem. Frontiers in Microbiology 4, 67.

Jiang, B., Liang, X., Chen, Y., Ma, T., Liu, L., Li, J., Jiang, R., Chen, T., Zhang, $X$. and Li, S. (2012). Integrating next-generation sequencing and traditional tongue diagnosis to determine tongue coating microbiome. Scientific Reports 2, 936.

Jin, H.-S., Park, S. Y., Kim, J.-Y., Lee, J.-E., Lee, H.-S. Kang, N. J. and Lee, D.-W. (2019). Fluorescencebased quantification of bioactive keratin peptides from feathers for optimizing large-scale anaerobic fermentation and purification. Biotechnology and Bioprocess Engineering 24(1), 240-249.

Jumas-Bilak, E., Roudière, L. and Marchandin, H. (2009). Description of 'Synergistetes' phyl. nov. and emended description of the phylum 'Deferribacteres' and of the family Syntrophomonadaceae, phylum 'Firmicutes'. International Journal of Systematic and Evolutionary Microbiology 59(Pt 5), 1028-1035.

Kanoksilapatham, W., Pasomsup, P., Keawram, P., Cuecas, A., Portillo, M. C. and Gonzalez J. M. (2016). Fervidobacterium thailandense sp. nov., an extremely thermophilic bacterium isolated from a hot spring. International Journal of Systematic and Evolutionary Microbiology 66(12), 5023-5027.

Kastritis, P. L., O'Reilly, F. J., Bock, T., Li, Y., Rogon, M. Z., Buczak, K., Romanov, N., Betts, M. J., Bui, K. H., Hagen, W. J., Hennrich, M. L., Mackmull, M.-T., Rappsilber, J., Russell, R. B., Bork, P., Berk, M. and Gavin, A.-C. (2017). Capturing protein communities by structural proteomics in a thermophilic eukaryote. Molecular Systems Biology 13(936), 1-14.

Kim, J. S., Kluskens, L. D., de Vos, W. M., Huber, R. and van der Oost, J. (2004). Crystal structure of fervidolysin from Fervidobacterium pennivorans, a keratinolytic enzyme related to subtilisin. Journal of Molecular Biology 335(3), 787-797.

Klindworth, A., Pruesse, E., Schweer, T., Peplies, J., Quast, C., Horn, M. and Glöckner, F. O. (2013). Evaluation of general 16S ribosomal RNA gene PCR primers for classical and next-generation sequencingbased diversity studies. Nucleic Acids Research 41(1), e1. 
Kubo, K., Knittel, K., Amann, R., Fukui, M. and Matsuura, K. (2011). Sulfur-metabolizing bacterial populations in microbial mats of the Nakabusa hot spring, Japan. Systematic and Applied Microbiology 34(4), 293-302.

Kultschar, B. and Llewellyn, C. (2018). Secondary metabolites in Cyanobacteria. In: Secondary Metabolites - Sources and Applications. Vijayakumar, R. and Raja, S. S. S. (eds.). IntechOpen. pp. 23-36.

Lau, M. C., Aitchison, J. C. and Pointing, S. B. (2009). Bacterial community composition in thermophilic microbial mats from five hot springs in central Tibet. Extremophiles 13(1), 139-149.

Lau, N. S., Zarkasi, K. Z., Sah, A. S. R. M. and ShuChien, A. C. (2019). Diversity and coding potential of the microbiota in the photic and aphotic zones of tropical man-made lake with intensive aquaculture activities: A case study on Temengor Lake, Malaysia. Microbial Ecology 78, 20-32.

Lee, Y. J., Dhanasingh, I., Ahn, J. S., Jin, H. S., Choi, J. M., Lee, S. H. and Lee, D. W. (2015). Biochemical and structural characterization of a keratin-degrading M32 carboxypeptidase from Fervidobacterium islandicum AW-1. Biochemical and Biophysical Research Communications 468(4), 927-933.

Magoč, T. and Salzberg, S. L. (2011). FLASH: Fast length adjustment of short reads to improve genome assemblies. Bioinformatics 27(21), 2957-2963.

Marteinsson, V. T., Hauksdóttir, S., Hobel, C. F., Kristmannsdóttir, H., Hreggvidsson, G. O. and Kristjánsson, J. K. (2001). Phylogenetic diversity analysis of subterranean hot springs in Iceland. Applied and Environmental Microbiology 67(9), 42424248.

Mehta, D. and Satyanarayana, T. (2013). Diversity of hot environments and thermophilic microbes. In: Thermophilic microbes in environmental and industrial biotechnology. Satyanarayana, T., Littlechild, J. and Kawarabayasi, Y. (eds.). Springer, Dordrecht. pp. 360.

Millard, A. D., Hands-Portman, I. and Zwirglmaier, K. (2014). Morphotypes of virus-like particles in two hydrothermal vent fields on the East Scotia Ridge, Antarctica. Bacteriophage 4, e28732.

Mohammad, B. T., Al Daghistani, H. I., Jaouani, A., Abdel-Latif, S. and Kennes, C. (2017). Isolation and characterization of thermophilic bacteria from Jordanian Hot Springs: Bacillus licheniformis and Thermomonas hydrothermalis isolates as potential producers of thermostable enzymes. International Journal of Microbiology 2017(6943952), 1-12.

Murakami, S., Fujishima, K., Tomita, M. and Kanai, A. (2011). Metatranscriptomic analysis of microbes in an oceanfront deep-subsurface hot spring reveals novel small RNAs and type-specific tRNA degradation. Applied and Environmental Microbiology 78(4), 10151022.

Nam, G. W., Lee, D. W., Lee, H. S., Lee, N. J., Kim, B. C., Choe, E. A., Hwang, J. K., Suhartono, M. T. and Pyun, Y. R. (2002). Native-feather degradation by
Fervidobacterium islandicum AW-1, a newly isolated keratinase-producing thermophilic anaerobe. Archives of Microbiology 178(6), 538-547.

Nazina, T. N., Lebedeva, E. V., Poltaraus, A. B., Tourova, T. P., Grigoryan, A. A., Sokolova, D. S., Lysenko, A. M. and Osipov, G. A. (2004). Geobacillus gargensis sp. nov., a novel thermophile from a hot spring, and the reclassification of Bacillus vulcani as Geobacillus vulcani comb. nov. International Journal of Systematic and Evolutionary Microbiology 54(6), 2019-2024.

Nishiyama, M., Yamamoto, S. and Kurosawa, N. (2013). Microbial community analysis of a coastal hot spring in Kagoshima, Japan, using molecular- and culture-based approaches. Journal of Microbiology 51(4), 413-422.

Panda, S. K., Jyoti, V., Bhadra, B., Nayak, K. C., Shivaji, S., Rainey, F. A. and Das, S. K. (2009). Thiomonas bhubaneswarensis sp. nov., an obligately mixotrophic, moderately thermophilic, thiosulfateoxidizing bacterium. International Journal of Systematic and Evolutionary Microbiology 59(9), 2171-2175.

Patel, B. K. C., Morgan, H. W. and Daniel R. M. (1985). Fervidobacterium nodosum gen. nov. and spec. nov., a new chemoorganotrophic, caldoactive, anaerobic bacterium. Archives of Microbiology 141(1), 63-69.

Quast, C., Pruesse, E., Yilmaz, P., Gerken, J., Schweer, T., Yarza, P., Peplies, J. and Glöckner, F. O. (2012). The SILVA ribosomal RNA gene database project: Improved data processing and web-based tools. Nucleic Acids Research 41(D1), D590-D596.

Satoh, T., Watanabe, K., Yamamoto, H., Yamamoto, S. and Kurosawa, N. (2013). Archaeal community structures in the solfataric acidic hot springs with different temperatures and elemental compositions. Archaea 2013, 723871.

Saxena, R., Dhakan, D. B., Mittal, P., Waiker, P., Chowdhury, A., Ghatak, A. and Sharma, V. K. (2017). Metagenomic analysis of hot springs in central India reveals hydrocarbon degrading thermophiles and pathways essential for survival in extreme environments. Frontiers in Microbiology 7, 2123.

Sharon, I. and Banfield, J. F. (2013). Genomes from metagenomics. Science 342(6162), 1057-1058.

Somboonna, N., Assawamakin, A., Wilantho, A., Tangphatsornruang, S. and Tongsima, S. (2012). Metagenomic profiles of free-living archaea, bacteria and small eukaryotes in coastal areas of Sichang island, Thailand. BMC Genomics 13(Suppl 7), S29.

Stetter, K. O. (1996). Hyperthermophilic procaryotes. FEMS Microbiology Reviews 18(2-3), 149-158.

Strasser, B., Mlitz, V., Hermann, M., Tschachler, E. and Eckhart, L. (2015). Convergent evolution of cysteine-rich proteins in feathers and hair. $B M C$ Evolutionary Biology 15, 82.

Suhaimi, N. S. M., Yeoh, S. Y., Nazari, T. F., Halim, M. A., Daud, F., Ibrahim, D. and Zarkasi, K. Z. (2019). Shrimp gut microbial community dynamic influence by the potential of shrimp feed additives of prodigiosin - 
An in vitro gut model. Malaysian Journal of Microbiology 15(6), 439-448.

Suzuki, Y., Tsujimoto, Y., Matsui, H. and Watanabe, K. (2006). Decomposition of extremely hard-to-degrade animal proteins by thermophilic bacteria. Journal of Bioscience and Bioengineering 102(2), 73-81.

Swingley, W. D., Meyer-Dombard, D. R., Shock, E. L., Alsop, E. B., Falenski, H. D., Havig, J. R. and Raymond, J. (2012). Coordinating environmental genomics and geochemistry reveals metabolic transitions in a hot spring ecosystem. PLOS ONE 7(6), e38108.

Takai, K., Nakamura, K., Toki, T., Tsunogai, U., Miyazaki, M., Miyazaki, J., Hirayama, H., Nakagawa, S., Nunoura, T. and Horikoshi, K. (2008). Cell proliferation at $122^{\circ} \mathrm{C}$ and isotopically heavy $\mathrm{CH} 4$ production by a hyperthermophilic methanogen under high-pressure cultivation. Proceedings of the National Academy of Sciences 105(31), 10949-10954.

Urbieta, M. S., Rascovan, N., Castro, C., Revale, S., Giaveno, M. A., Vazquez, M. and Donati, E. R. (2014). Draft genome sequence of the novel thermoacidophilic archaeon Acidianus copahuensis strain ALE1, isolated from the Copahue volcanic area in Neuquen, Argentina. Genome Announcements 2(3), e00259-00314.

Wang, Q., Garrity, G. M., Tiedje, J. M. and Cole, J. R. (2007). Naive Bayesian classifier for rapid assignment of rRNA sequences into the new bacterial taxonomy. Applied and Environmental Microbiology 73(16), 52615267.

Watnick, P. and Kolter, R. (2000). Biofilm, city of microbes. Journal of Bacteriology 182(10), 2675-2679.

Wemheuer, B., Taube, R., Akyol, P., Wemheuer, F. and Daniel, R. (2013). Microbial diversity and biochemical potential encoded by thermal spring metagenomes derived from the Kamchatka Peninsula. Archaea 2013, Article ID 136714.

Wilson, M. S., Siering, P. L., White, C. L., Hauser, M. E. and Bartles, A. N. (2008). Novel archaea and bacteria dominate stable microbial communities in North America's Largest Hot Spring. Microbial Ecology 56(2), 292-305.

Yeo, I., Lee, Y. J., Song, K., Jin, H. S., Lee, J. E., Kim, D., Lee, D. W. and Kang, N. J. (2018). Low-molecular weight keratins with anti-skin aging activity produced by anaerobic digestion of poultry feathers with Fervidobacterium islandicum AW-1. Journal of Biotechnology 271, 17-25.

Zarkasi, K. Z., Halim, M. A., Nazari, T. F. and Daud, F. (2018). Metagenomic data on Anadara granosa associated bacterial communities using culture dependent approaches and 16S rRNA sequencing. Data in Brief 19, 514-519.

Zarkasi, K. Z. and Nazari, T. F. (2018). Molecular characterisation of microbial diversity associated with oysters within a commercial oyster farm. Turkish Journal of Fisheries and Aquatic Sciences 18, 191197.
Zarkasi, K. Z., Taylor, R. S., Glencross, B. D., Abell, G. C., Tamplin, M. L. and Bowman, J. P. (2017). In vitro characteristics of an Atlantic salmon (Salmo salar L.) hind gut microbial community in relation to different dietary treatments. Research in Microbiology 168, 751-759.

Zarkasi, K. Z., Shukri, A. A. A., Nazari, T. F., Abdullah, A. A. A. and Daud, F. (2019). Molecular characterization of microbial community diversity associated with blood cockle (Anadara granosa) in the blood cockle farms. Jordan Journal of Biological Sciences 12(3), 339-344. 